\title{
CONCEPT OF NATIONALISM EMPLOYED IN THE GOLDEN LEGEND BY NADEEM ASLAM
}

\author{
Shaista Shahzadi $^{1 *}$, Muhammad Hanif ${ }^{2}$, Ali Ahmad ${ }^{3}$, Hira $\mathrm{Ali}^{4}$, Mehnaz Kousar $^{5}$ \\ ${ }^{1 *}$ Lecturer, Department of English, NUML, Multan, Pakistan; ${ }^{2.3}$ Lecturer and Assistant Professor, Department of \\ English, COMSATS, Vehari, Pakistan; ${ }^{4}$ Lectuer, Department of English, University of Sargodha, Pakistan; ${ }^{5}$ Student, \\ NUML, Multan, Pakistan. \\ Email: *shahzadi.shaista@yahoo.com
}

Article History: Received on $26^{\text {th }}$ March 2021, Revised on $29^{\text {th }}$ June 2021, Published on $30^{\text {th }}$ June 2021

\begin{abstract}
Purpose of the study: The main purpose of this study is to analyze the novel The Golden Legend by Nadeem Aslam in the light of the concept of Nationalism given by Benedict Anderson in Imagined communities.

Methodology: The entire data is evaluated by the entire text related to nationalism. This research is based on qualitative research skills. The basic resource of this research is the novel of Nadeem Aslam, named The Golden Legend. Further, the other resources used in this research are the journals or the articles regarding or reflecting the explanation of this novel (The Golden Legend).

Main Findings: The findings depict a wonderful series of characters who have humanity in their hearts; they have love and respect for others, either the other person is from their religion or a different one. It is a story of sorrow and the game of religions in the world which is being played under the acts of the political authorities.
\end{abstract}

Applications of this study: This study can be applied to the nationalism literature.

Novelty/Originality of this study: The study is one of its kind because, after a careful analysis of the literature available, it is safe to say that no study is done up till now on analyzing the concept of nationalism in the Golden Legend.

Keywords: Nationalism, Employed, Golden Legend, Benedict Anderson, Imagined Communities.

\section{INTRODUCTION}

The major objective of this study is to analyze the Golden Legend by Nadeem Aslam, that how the writer has explained the basics of nationalism and what kind of events are involved in the uprising of nationalism. This study has used Benedict Anderson's concept of Nationalism for analyzing the Golden Legend. A publication of Benedict Anderson, which was published in 1983 in Imagined Communities, because of which he is known as one of the first thinkers of nationalism. In his book, Imagined Communities, Benedict Anderson explained the situations of the rising of Nationalism in the past. The writer explained nationalism in this manner that the entire nation is like an imagined community. The reason for this assumption is that either people know one another or not; they know that it is a community in which they live. This entire study is to take the overview of this novel named the golden legend by Nadeem Aslam.

\section{Background of the Study}

The author of this novel is an exciting novel writer. His major work is usually linked with fiction and sometimes is regarding honor killings, religious wars, or terrorism wars. The first novel of the writer was Season of the Rainbirds, which was published in 1993, which is basically about the community of Pakistan (a ruined community because of the murderous trend in political history). He also explained the destruction of the Pakistani community in the context of historical references; in another novel, "The Waste Vigil," which was published in 2008, he described the major causes of the 9/11 attacks on the world trade Centre and also explained the reasons for the Soviet Union invasion in Afghanistan (Smith, 2000; Lemke, 2008; Butt, 2008; Flannery, 2013). This novel of Nadeem Aslam is a reliable resource of historical events and also has information about the people in this entire world. In his novels, he has a wide range of characters related to different locations and religions in this world. He has discussed the different manners and historical events in his books, specifically regarding Pakistan, the USA, and Afghanistan. Aslam has also poured the light on the bitter components of Islam, such a sequence of events has been mapped in another novel, which was published in 2004, named as maps for Lost Lovers, and also in a short story by him, named Leila in the wilderness, published in 2010. In his final two books, he has revisited the origin of the nation. These two books are "the Blind man's garden," published in 2013, and the last one was the Golden Legend, published in 2017. All the books of the Nadeem are written in such an expository manner in the tribute of the pundits for their excellence in doubling up the issues related to fear. The concept of nationalism is incorporated in this novel by Benedict Anderson, one of the first thinkers of nationalism.

Benedict brought his theory when he found neither the Marxist school of nationalism nor the liberal school of thought as satisfiable as it should be. Benedict is known as the historian regarding the nationalism school of thought. He has assumed that all the countries in the world and the world's entire nationalism are the result of the financial and political revolutions; he also said that motivated people are the resource of the social building. Benedict has not combative nature 
and did not think the patriotism as an old weapon in this age of globalization. He also thinks of an ideal school of thought of nationalism (Anderson,1983). The entire thought of these motivating thoughts in this modern age that how these nations set the objectives to be implemented during the international management of matters. E.g., the data management of the foreign peoples and about the data of migration of people from one country to another. In one of Benedict's books named "Imagined communities," he has explained the concept of a nation that belongs to a social network of people in the world. It also discussed that all types of bonding linked with the community are an artificial thought of being a group member. Benedict has paid heed to the difference between right and wrong but by the same concept by which these are known to the people. Anderson said that it is said to be an imagined school of thought because not all the people know each other's is the reason of the imagined school of thought that it limits the people to their artificially made concepts for being in contact with their people in nearby (Anderson, 1983). Benedict also described that nationalism is based on the basic principles of the culture, which belonged to the economic and political activities involved in this culture to hold up the nation.

\section{Research Objectives:}

The objective of this research study is:

- To determine the entire concept of nationalism as explained in the novel named as the golden legend written by Nadeem Aslam.

\section{Research Questions}

How is the concept of Nationalism working in the novel The Golden Legend by Nadeem Aslam?

\section{Significance of the Study}

This research is significant because it gives a new perspective of analyzing the novel The Golden Legend. Through this perspective, the concept of nationalism is more clearly understood by the readers.

\section{Delimitations of the Study}

This research is limited to only Nadeem Aslam's novel (The Golden Legend). The novel has religious, political, environmental, and cultural strategies, but the purpose of this study is only to find out how the concept of nationalism is working in the novel The Golden Legend.

\section{LITERATURE REVIEW}

In this section, the reviews of the previous work related to this novel, "the Golden Legend," are included. This chapter is necessary to determine the research work extent up till now about this novel.

In his article (Reading as resistance), a researcher named Miller (2019) stated his article (Reading as resistance) that the novels of Nadeem Aslam usually involved modern fiction writing. He termed the fiction of Nadeem as "Soul Hefty Fiction." The story of this novel has shown the entire world and the school of thoughts of the people living in this world. In this novel of Nadeem Aslam named as "The Golden Legend," the stories of Nadeem has welcomed the readers of his stories towards the mutual relationship betterment, as like the characters of this novel has built the relations among themselves without keeping the consent of the outer world (Morey, 2018; Rahman, 2020; Liaqat \& Raza, 2020; Rahman, 2020; Nazir, 2020). As Nazir (2020) described the novels and stories of Nadeem Aslam, they stated that Nadeem's stories provide the core of love, piousness, misfortunes on the higher levels which can affect the political or social common. Several scholars (Veyret, 2021; Sukheeja, 2017; Shamsie, 2017; Cilano, 2009) have stated about the novels of Nadeem, that he specifically focuses on the individual characters than the other participants of the story. This novel of Nadeem Aslam shows the results of his findings related to personal relations and interconnectedness and shows the difference between the imaginary and real modern world. He said that people usually found a closer network of loving and helpful people in this world full of restrictive behaviors. To show these characters as original, Nadeem has created these with the human psychological effects and the emotions. Another writer, named Kaur (2018) has analyzed the novel of Nadeem The Golden Legend and showed his analysis in his article named "Challenging the Myth of purity" that the minorities in Pakistan are oppressed from the beginning, from the day of independence, these minorities are usually based on the religious differences. He says that a group of people can bring change and can recycle the structure of their lives. Nadeem has tried to show the culture of being helpful and which is free from religious differences and any other kind of discrimination.

It is showed that the entire nation is under the control of higher authorities who do not want to bring the minorities to the mainstream and always try them to be in the lower zone of the nations and keep underestimating their capabilities. This story of Nadeem shows the imagined community, which is not far different from the modern and real community or society. He also stated that the Pakistani government has underestimated the various minorities and never took them as part of the nation collaboratively. He also said that there is a dire need to get together against the external nations instead of converting towards extremism. Another writer named Scanlan (2018), in her article (Straight Forwardness into haziness), discussed the 9/11 case in contrast to Nadeem' novel named (the wasted vigil in 2008 and the Blind's man garden in 2013), she discussed the USA troops involved in the war in Afghanistan due to which the USA also involved 
Pakistan in this war and played from behind Pakistan. Nadeem Aslam is a British novelist who analyzed the condition of the USA and Pakistan from a closure review. Aslam, in his novel about 9/11, described the story instead of in the context of a historical event or straightforward story from an artistic point of view, he described the political darknesses and social discriminations based on a different school of thoughts as of Pakistani or of USA (Liaqat \& Raza, 2020). He brought the difficulties to light faced by the people involved in that war on terror and the Afghan war.

Another writer named Flannery (2013) stated in her article that some novelists present their bitter life experiences. Some create the entire universe in their novels or writing, but Nadeem Aslam is the only writer who has been chosen for the Booker prize twice, and he is the man who can create the entire universe in their writings. His writings are full of the pattern of living the life, history, and rituals of the Muslim cultures or the belongings of the Muslim culture such as Pakistan, Afghanistan, Kashmir, and India. In this novel, The Golden Legend, he introduced the two main characters, a couple named Nargis and Massud, who was thinking against the entire world and the customs of society; they were living in a society where the Christians were locked as the minority nation. In this novel, he tried to show the way of thinking which Massud and Nargis were thinking about the world; they built a mosque on an island where they want to unite the people from all the sects of Islam under one roof in the command prayer.

The entire literature which is reviewed for this study, in the context of the novel of Nadeem Aslam named "The Golden Legend," showed that all the researchers, other writers, or novelists have discussed this novel from a different point of view but not in the context of nationalism which was one of the main and important points to be overviewed. So, this is the research gap to be discussed and fill this gap by analyzing the concept regarding nationalism in this novel (The Golden Legend) of Nadeem Aslam.

\section{METHODOLOGY}

In the section, the concept provided by the benedict Anderson in his book named "Imagined communities" is described. The entire data is evaluated by the entire text related to nationalism. This research is based on qualitative research skills. The basic resource of this research is the novel of Nadeem Aslam, named The Golden Legend. Further, the other resources used in this research are the journals or the articles regarding or reflecting the explanation of this novel (The Golden Legend). This is by the book of Benedict, known as Imagined communities which was published in 1983 . He said that people are linked with a thought of nation in the entire world, making them a community.

E.g., the songs, the flags, etc., he said that people usually consider themselves a part of some group which they are imagining. This artificial imagined community concept is usually based on pictures or any other kind of media which can be used to demonstrate the concept of community. He said that the media is a resource for getting the communal identity. These nations and communities can be expressed in various ways. Benedict also discussed a little about the foundation of these nations. Benedict also explained the concept of a community that covers all the nations or people in the world. By the concept of the nation as described by the benedict, there are four characteristics of the Islamic groups: the imaginary, limitations, sovereignty, and the community. Anderson also defined the nation as the brotherhood (Anderson, 1983). Benedict also evaluated how these nations came into being, that in this respect, all the aspects of the community can be visualized. All the people in the world can beholder each other. The nation and communal identity of the people as imagined but free from linguistic differences and borderlines, as defined by Anderson which could account for the basic concept of the actual nation.

\section{DISCUSSION/ANALYSIS}

In this section, the novel named "The Golden Legend" is evaluated after observing how nationalism is explained by the benedict Anderson in the novel.

In the context of Pakistani culture, as written in the English novels that the nationalism is an expressive thought of this culture. The English writer of Pakistan has expressed this thought in the form of the subcontinent, like the communities, and in the 9/11 activities. Aslam (2017) also describes the religious differences and discrimination and also explained the concept of Zamana in which he explained the religion and the violence related to this. Anderson (1983) also defined the nation as a political community that is imagined as sovereignty. This nonexistent neighborhood which pours light on the different religious school of thoughts which is the major point discussed in this novel. In the Zamana concept, there are community schools of thought are involved overall in this novel. Benedict also talked about the nation and the people of particular communities who know each other in Imagined Communities. It is especially the exact concepts to be used, as in the case of Massud and Nargis, who are the main characters of this novel. Massud and Nargis are senior citizens in the Zamana who have a Christian servant with them along with his daughter. In their entire life, which has been passed, they have faced so many difficulties in their life due to the basic religion of Nargis (Aslam, 2017). As Nargis was a Christian but to cover up religious discrimination and cover up her original religion, she changed her name to Nargis as a Muslim name. She began to start living like the Muslims. Even after so many years of living as a Muslim, she was unable to understand what to do because her entire life was based on the fraud, all the love she has was not real, but none other than a fraud, all of this shows that no one can understand the matter until that person tells something about that matter and it also depends upon what they tell.

After the unexpected death of Massud, Nargis was being treated unfairly when she becomes nearer to Helen and lily for 
seeking some comfort. Another tragedy she has faced at that time when this secret of love is revealed publicly is that lily and a daughter of an Imam-e-Masjid are in love. People in nearby areas got angry at this homosexual affair of the lily and the daughter of that imam-e-masjid. They started destruction and the burning of houses and buildings. According to the text of the novel, it is stated that lily and the daughter of that imam both have committed a sinful crime which is punishable by only death. Lily broke out from the town, due to which the people who were in the rage of such a sinful act started targeting the Christians in that town, due to which Helen and Nargis had also broken out of the town to escape from their sight. In this critical condition and an unrested situation, a person a former member of the anti-militant army groups in Pakistan, whose name was Imran, said that he was never involved in the brutal and violent activities because Pakistan was built on the slogan as the symbol of peace, He saved both the Helen and Nargis. He told them that he was willing to help the Kashmiris people to fight against Indian brutal activities and their practices of injustices on Kashmiri peoples, but the Pakistani government did not treat him and others like him well.

Imran, Nargis, and Helen all three broke out to an island, which is reflecting as a perfect symbol of liberty, an exact and pure free place. Here, they all become friends on this island while Helen and Imran fell in love with each other. They started living in that mosque built by the Massud and Nargis in the context of a holy thought of getting all types of religions in here, on the same platform. That mosque is usually considered the symbol of peace for all the sects and religiously oriented groups towards one platform to show peace in Pakistan. The basic thought of Massud behind building this mosque, all the four sects of Islam will be gathered here to perform a common prayer may be all enter from different doors of the mosque, but all will offer prayer as one community. It can be seen that this mosque is the symbol of unity of all the sects of Islam. This mosque reflects an imaginary school of thought of nationalism that was not included in the real world in which both Nargis and Massud lived; they were the town's denizens in which people were against Christianity. This thought of bringing all the sects under one roof for the common prayer was imaginary, but as mentioned in the novel that the circumstances were not feasible to this thought. Different sects were attacking one another's sect, even the death speeches were also not respected, while under such an outer situation, intrapersonal thoughts of the people were different from this as described by the character of Massud and Nargis.

Nargis was accused of not only being responsible for the breaking off of Lily and the daughter of the imam. Now in here, the people of that town were not only against the homosexual affair of those two girls and also, but they were also willing to abolish Nargis from changing her religion without any consent. The policemen were continuously forcing Nargis to show forgiveness for the killer of her husband, Massoud. In her heart, she knows that police have killed Lily and her lover girl, but she was still asking to release her friends, Helen and Imran.

To be a participant of any nation, it is necessary to have some special qualities. In this novel, it is reflected that in Zamana, the religion and religious forces were ruling the nation. The core thought of the creation of Pakistan was to be the Muslim nation as a leading and decisive authority as benedict stated in his definition of the nation to elaborate the Pakistani nation that was made for the Muslims. A place where the minorities did not have the same liberty as Muslims have. The minorities in Pakistan are oppressed from the beginning, from the day of independence; these minorities are usually based on religious differences (Kaur (2018). In this novel, the golden legend also discussed that the Christians are different from the Muslims, though both nations, i.e., the USA and Pakistan, have the same religious base. It is stated that in Zamana, the Christians were considered as a lower nation in the context of race and religious basis. This is the same feeling which is being floated in Pakistan. The Christians of that time were treated in a bad manner and considered as black blood. This was said by a young Muslim girl to Helen because the Muslims were trained and brainwashed against the Christian community at that time. Although Nargis's real name was Margaret, and she was born a Christian. As a teenager, she adopted the name Nargis and pretended to be Muslim to escape the harsh oppression faced by Christians in Pakistan.

Benedict said that the nation is a communal gathering or a group which puts all of its members together Anderson (1983). The reality of the nation is another issue without being collaboratively for various nations. In the Zamana, and the people of the time after Zamana were based on the objective of having and living a decent life. In the Zamana, Massud, and Nargis, with lily, her Christian servant, and her daughter Helen, lived in their little world where there were no religious discriminations in here and no superiority or minority based on religion or culture. This little world made by Massud Nargis was based only on respect and the love between them without any differences. While the Zamana was full of religious discrimination and anti-nationalism, and sectarianism. People who commit a sinful crime in the eyes of those people, the house of those people were burnt without any reason for the sake of their punishments the other hand, the relation between the Nargis, Massud. With their servant, lily was truly based on love. Now, at this time, the purpose of the creation of Pakistan is not truly fulfilled, and it also looking oppositely as this was based on the equality of all the sects or religions because it was the land demanded based on Islam and Islam allows freedom of religion. Zamana was a brutal picture of humanity depicting the inequality with the other religions under the blanket of Islam. Zamana is rife with violence against individuals in the name of religion. Muezzin has sung songs about the young jihadi boys, the rape of little girls, and the open killings of the people.

In this novel, the character of Imran was showing the constituent of the imagined community. Imran was against India because his mother was attacked by the Indian officers and got pregnant. In the rage of this, Imran got involved in the militant group which was working in Kashmir against Indians, but after some time, Imran found out that the guerilla 
force of those militants in Kashmir are also killings the Muslims there, so he returns to the Zamana from there. As stated in the novel, Anderson (1983) talked about the group attacking that the pics from local people were sent to the authorities to whom they want to make some relation.

According to the concept of nation, the basic need is stability and a sense of secureness from the side of politics. He also stated that the nations are not only dependent on feminine relations but also depending upon the political stability in the country or nation. In this novel, Nargis has talked about the brother of Massud, who was a reporter and a journalist and was searching for evidence of the military agencies case; he was found dead one day. This kind of action shows that the higher authorities of the country remove their obstacle in the political activity planning made by them. Massud's children were killed due to the act of Massud of assuring the denizen about removing the cover from the intelligence agencies' activities. Massud was also killed under a political activity; Nargis was forced to forgive the murderer of Massud, who was an American agent. It shows that the country has been in control of political activities. in this novel, the life of Massud, who was an Engineer was not worthy Infront of the political activities. The life of an engineer, Massud, is by all accounts futile for the country state projected in the novel. Burhan, An Army person, reminded Nargis that you should be strong as the world is not ended yet. This kind of activity is also showing the disrespect of the people in front of the political personalities.

According to history, it is concluded that religion has answered to the issues which the people in nowadays, in the nation are facing. The various nations have answered the issues regarding life, death, etc., for the life of Massud; it can be said that it was all good. He served the nation in a very decent manner. Massud imagined a mosque where all the sects of Islam offer the common prayer under one roof. He considered removing the shoes before entering the mosque that the people are entered in a purge faith. He also considered leaving any harmful weapon outside of the mosque before entering here to symbolize the extreme goodness and pureness of spirit. It can be seen how perfect and unbelievable the sense of thought Massud have, which afterward became the reason for his death and how the higher authorities used it for their political acts.

As for Nargis, her life was full of tragedies, and her nation has not protected her as a child, her original name at the time of birth was Margaret, which afterward changed to Nargis to live a presentable life as a Muslim. Massud was also not aware of her original religion and name. Nargis showed that it is difficult to truly understand the same's religion or nation in the entire novel. If she had told her husband or anyone else about her life events or her true religion or name, her life would be ruined before starting. According to the writer, Nadeem Aslam, the entire life of Nargis was a lie and surrounded by it. Major Burhan, an Army person, forced Nargis to forgive the murderer of her husband Massud and blackmailed her that he will tell the world about her original religion and it would be considered not less than a sinful act that a Christian woman is living the life of a Muslim without any proper conversion of religion procedures. It is another example of nationalism that she lived her entire life as a Muslim being of the other religion.

Nationalism nowadays symbolizes the higher authorities' influence in a very effective manner in the education systems. Due to this advanced level of education, the young candidates of the nation are grown to be loyal to the country and the nation. Nationalism is also showing the symbol of using people's feelings for the nation to remain in power. The people of the nation usually have to surrender themselves for the sake of their nation. The case of an Engineer, Massud, was also regarding this example of how the higher authorities of the nation have forgiven his murderer, who was an American spy, and that the government has to keep good political relations with the Superpower America. Major Burhan blackmailed Nargis for forgiving that murderer.

That island on which Nargis and Massud built that mosque, where Helen, Imran, and Nargis were living after breaking out from their town. By their relations, it can be seen that there are no social differences and religious discriminations between them. This island is the symbol of the basic Pakistani thought which was in the air before the partition of the sub-continent. It was also envisioned that Pakistan is the place where people of varying religions and sects can live without discrimination, the same place as that island were those three, Imran, Nargis, and Helen were living together with love and the relation of friendship. In this novel, the imagined communities have visualized that island of being a peaceful place in the world, relating to Pakistan as similar to this. Nargis remembered this island with her husband while she was on this island with Imran and Helen. Massud and Nargis, as architects, have designed that mosque to unite all the sects of Islam under one roof; they also planned to build a temple for the Hindu community and a church for the Christians. The island was meant to be a unifying place for all Muslims, putting an end to sectarianism. They also planned to build a temple for Hindus and a church for the Christian community. However, they have to leave that island because of the murder in that mosque which shows the disrespect of this holy place. The idea of Massud and Nargi to provide a Peaceful state remained unfulfilled. Now, the three Imran, Helen, and Nargis live in that place, hiding from that brutal world, and Nargis also sometimes thinks that God has created that world.

Anderson (1983) stated that it is the communal share of the society which reflects a nation in which they live. Though in the novel, the Pakistani people are divided into different groups based on religions and different groups. Nowadays, the political conditions of Pakistan can be seen as situations of brittleness and violence in the region of Zamana. This novel states that the individuals are at the second level while the politics is on top. Also, Pakistan is a country that cannot stand against the will of the superpower America; that's why major Burhan forced Nargis to forgive that American man who killed her husband, Massud. The brother of Massud was also killed as he was involved in the intelligence activities. 


\section{CONCLUSION}

To conclude, this novel of Nadeem, named the golden legend, depicts the nation of Pakistani's and the Muslim community along with Christians. In this story of religions, the writer has created a wonderful series of characters with humanity in their hearts; they have love and respect for others, either that another person is from their religion or a different one. The novel named the golden legend by Nadeem Aslam is a story of sorrow and the game of religions in the world which is being played under the acts of the political authorities. It is based on the Pakistani Hindu culture and the famous story of being one nation and acting like one nation. It also depicts the story of the nation, which shows a culture in which Christians use to burn their houses and kill those who were involved in any sinful activity. Nadeem's novel is a symbol of love, peace, and humanity.

\section{LIMITATION AND STUDY FORWARD}

The study is limited to the concept of nationalism. However, further study can be done on analyzing the novel linguistically by applying the theory of power by Fairclough.

\section{ACKNOWLEDGEMENT}

The credit goes to the writers solely as the work is done by their creativity.

\section{AUTHORS CONTRIBUTION}

The first author wrote the introduction and analysis, the second wrote the literature review and half part in the discussion, the third wrote the conclusion, the fourth did the formatting, and the fifth did the suggested changes by the journal.

\section{REFERENCES}

1. Anderson, B. (2001). Asian Nationalism? New Left Review, 9, 31.

2. Anderson, B. (1983). Imagined communities: Reflections on the origin and spread of nationalism. Verso books.

3. Aslam, N. (2017). The Golden Legend: A Novel. Vintage.

4. Brians, P. (2003). Modern South Asian Literature in English. Greenwood Publishing Group.

5. Butt, N. (2008). Between orthodoxy and modernity: Mapping the transcultural predicaments of Pakistani immigrants in multi-ethnic Britain in Nadeem Aslam's Maps for lost lovers (2004). In Multi-Ethnic Britain 2000+ (pp. 153-169). Brill. https://doi.org/10.1163/9789401206587_012

6. Calhoun, C. (2016). The importance of imagined communities-and Benedict Anderson. Debats. Revista de cultura, poder i societat, 1. https://doi.org/10.28939/iam.debats.130-1.2

7. Chambers, C. (2011). A comparative approach to Pakistani fiction in English. Journal of Postcolonial Writing, 47(2), 122-134. https://doi.org/10.1080/17449855.2011.557182

8. Cilano, C. (2009). "Writing from Extreme Edges": Pakistani English-Language Fiction. ARIEL: A Review of International English Literature, 40(2-3).

9. Cilano, C. (2013). Contemporary Pakistani fiction in English: Idea, nation, state. Routledge. https://doi.org/1 $\underline{0.4324 / 9780203552247}$

10. Clements, M. (2013). Orienting Muslims: Mapping global spheres of affiliation and affinity in contemporary South Asian fiction (Doctoral dissertation, University of East London).

11. Desai, R. (2008). Review Essay: The inadvertence of Benedict Anderson: A review essay of Imagined Communities on the occasion of a new edition. Global Media and Communication, 4(2), 183-200. https://doi.org/10.1177/1742766508091519

12. Desai, R. (2009). The inadvertence of Benedict Anderson: engaging imagined communities. The Asia-Pacific Journal, 11(51), 2-9.

13. du Dot, M. J. (2019). Mapping the unstable: the Af-Pak border and its tropes in Nadeem Aslam's The Blind Man's Garden (2013). Représentations dans le monde anglophone, 1.

14. Flannery, E. (2013). Internationalizing 9/11: Hope And Redemption In Nadeem Aslam's The Wasted Vigil (2008) And Colum Mccann's Let The Great World Spin (2009). English, 62(238), 294-315. https://doi.org /10.1093/english/eft010

15. Ivanchikova, A. (2017). Imagining Afghanistan in deep time: Nadeem Aslam and the aesthetics of the geologic turn. MFS Modern Fiction Studies, 63(2), 288-311. https://doi.org/10.1353/mfs.2017.0023

16. Kaur, S. (2018). Contesting the Myth of Purity: An Analysis of Nadeem Aslam's The Golden Legend in the light of Jean-Luc Nancy's Insight. The Vedic Path, 93(4), 51-75.

17. Lemke, C. (2008). Racism in the diaspora: Nadeem Aslam's Maps for lost lovers (2004). In Multi-Ethnic Britain 2000+ (pp. 171-183). Brill Rodopi. https://doi.org/10.1163/9789401206587 013

18. Liaqat, Q., \& Raza, A. (2020). Diasporic Intertextual Musings: The Relevance of Classical Urdu Poetry to Contemporary Pakistani Situation in Nadeem Aslam's The Golden Legend. NUML Journal of Critical Inquiry, 18(1).

19. Miller, B. (2019). Reading as Resistance. The Comparatist, 43, 341-355. https://doi.org/10.1353/com.201 
$\underline{9.0018}$

20. Moore, L. (2009). British Muslim identities and spectres of terror in Nadeem Aslam's Maps for lost lovers. Postcolonial Text, 5(2).

21. Morey, P. (2018). Chapter Six. Islamophobia and the Global Novel: "Worlding" History in Nadeem Aslam and Kamila Shamsie. In Islamophobia and the Novel (pp. 183-210). Columbia University Press. https://doi.org/10.7312/more17774-008

22. Nazir, B. (2020). Brand Pakistan: a reception-oriented study of Pakistani Anglophone fiction: a dissertation presented in partial fulfilment of the requirements for the degree of Doctor of Philosophy in English Literature at Massey University, Palmerston North, Manawatu, New Zealand. Currently unavailable until further notice (Doctoral dissertation, Massey University).

23. Rahman, S. (2020). Animals, others, and postcolonial ecomasculinities: Nadeem Aslam's The Blind Man's Garden. The Journal of Commonwealth Literature, 0021989420952125. https://doi.org/10.1177/0021989 420952125

24. Rahman, T. (2020). Pakistani English. The Handbook of Asian Englishes, 279-296. https://doi.org/10.1002/9 781118791882.ch11

25. Scanlan, M. (2018). Transparency into opacity: Nadeem Aslam's alternative to the 9/11 novel. European Journal of English Studies, 22(2), 103-114. https://doi.org/10.1080/13825577.2018.1478254

26. Shamsie, M. (2017). Pakistani-English Writing. In Oxford Research Encyclopedia of Literature. https://doi.org/10.1093/acrefore/9780190201098.013.69

27. Shoaib, M. (2020). Imprecise Attacks, Invisible Victims: Representation of Drone Warfare in Selected Post9/11 Pakistani Fiction. Journal of Research in Humanities, 56(2), 31-44.

28. Smith, A. D. (2000). TheSacred'Dimension of Nationalism. Millennium, 29(3), 791-814. https://doi.org/10.1 $177 / 03058298000290030301$

29. Sukheeja, V. (2017). Violence and Hope in Nadeem Aslam's The Golden Legend. Language in India, 17(12).

30. Veyret, P. (2021). Fractured territories: Deterritorializing the contemporary Pakistani novel in English. The Journal of Commonwealth Literature, 56(2), 307-321. https://doi.org/10.1177/0021989418808039 